\title{
THE RISE OF POPULISM, THE DEMISE OF THE NEOLIBERAL AND NEOCONSERVATIVE GLOBALIST PROJECTS, AND THE WAR ON HUMAN RIGHTS
}

Dr Darren J. O’Byrne

\begin{abstract}
For many, the "Trump phenomenon" represents an authoritarian phase of the neoliberal project. For others, it is a manifestation of a broader populist project that is the antithesis of, and arises in part as a reaction against, neoliberalism. Across Europe, political parties hitherto identified with the Far Right and thus beyond the margins of "respectable" politics have sought to reinvent themselves as legitimate voices within this populist framework. The UK "Brexit" vote and the policies of the May administration further suggest a coalition emerging around the Far Right and those on the nationalist wing of conservatism, putting them at odds with the neoliberals and neoconservatives who have dominated the political Right for some time, and who have been the principal drivers of capitalist globalization. This begs the question - does the new populism signal the end of the globalization project? And what, if anything, can the Left do in response?
\end{abstract}

\section{Introduction}

Among recent events, the election of Donald Trump to the American presidency and, preceding it, the outcome of the UK referendum on membership of the European Union (the so-called 'Brexit' vote) have been heavily debated and dissected by 'experts' and lay commentators alike. Both, of course, were for the most part unexpected: opinion polls and expert analyses in both cases seemed to suggest alternative outcomes. Both also signalled a clear break with the recent past and, from the public perspective, with the 'established' political order.

In both cases, sections of the liberal media and the political Left have treated these two unexpected outcomes as manifestations of the worst qualities of our peoples, expressions of a racist isolationism stirred up by reactionary forces. It is easy, for example, to read the election of Trump as a manifestation of the kind of American insularity and exceptionalism cleverly dissected in a recent memoir by Suzy Hansen (2017), or to reduce 'Brexit' to some kind of innate xenophobia among the older generation. The reality, of course, is considerably more complicated. If Brexit was all about petty nationalism, why did large sections of the political Left campaign for it? To better understand the apparent popularity of Trump, should we not also consider the relative success of left-wing populist Bernie Sanders, who came closer than expected to securing the Democratic Party ticket? The 'common denominator' seems to be that Brexit, Trump and Sanders 
are all manifestations of a general dissatisfaction with the so-called 'metropolitan' - and more precisely, 'cosmopolitan' - elite.

Any number of demographic indicators can be used to demonstrate this point, not least social class and geographical location. The 'Brexit' vote, for example, was highest across England, with the obvious exception of Greater London, where the vast majority of voters opted to remain. A sizeable majority of the Trump support come from the US interior - he is decidedly less popular in the major coastal cities such as New York and Los Angeles. The aforementioned 'common denominator' reminds us that it is the primarily working-class populations of the increasingly run-down industrial cities that have been disenfranchised by the neoliberal globalist project run by and in the interests of the metropolitan centres. There is of course truth in this - even within these richest of rich countries there is a growing post-industrial underclass denied access to the means, never mind the benefits, of the globalizing process. One can certainly read these as protest votes against the perceived metro-centrism and cosmo-centrism of the 'mainstream' political voices, although in doing so there is a danger of assuming that the protest will come and go and 'normal service will be resumed', without paying sufficient attention to the underlying socio-economic conditions which ignited the protests in the first place.

This article, though, is not intended to be a contribution to these debates, rather it is an attempt to understand them within the context of political ideology. Both the election of Trump and the rejection of continued EU membership (together with the apparent rise in influence of the hitherto-fringe UK Independence Party) are indicative of a new right-wing populism in politics, sandwiched on the political spectrum between the ultra-nationalistic, fascist Far Right and the mainstream conservative movement. While for some, this is a further expression of the project of 'neoliberalism', my argument is that contra neoliberalism this populism represents a somewhat sanitised, publicly 'acceptable' manifestation of fascism. It is constructed in the transition within fascism from a supremacist to a separatist ideology, and is consciously at odds with both neoliberalism and its distinct but closely associated cousin, neoconservatism. Whereas neoliberalism and neoconservatism in different ways embrace the globalist project, and in a very specific sense its associated projects of human rights and cosmopolitanism, fascism is an outright rejection of it, and thus derives from an entirely different 
sentiment. The new populism is an articulation of this sentiment rather than the other.

This paper is intended to present a largely speculative account. A more empirical analysis would ideally use policy and discourse analysis to demonstrate the extent to which the rhetoric of the new populists is rooted in the fascist tradition. My purpose though is to present the conceptual framework for such an analysis through:

(I) An account of the neoliberal and neoconservative globalist projects through a dissection of the ideologies of neoliberalism and neoconservatism;

(II) An introduction to the new populism as a distinct political ideology with its roots in fascism, first through an overview of the transformations within Far Right parties in the UK and across Europe, then through parallels that can be drawn with the US;

(III) A demonstration of how, contra neoliberalism and neoconservatism, the new populism is engaged in a 'war on human rights' rooted in its commitment to deglobalization.

\section{The Neoliberal and Neoconservative Globalist Projects}

The tendency to over-use, and therefore misuse, the term 'neoliberal' particularly in a pejorative sense by the Left - often obscures a lack of understanding on what the term might actually mean. Despite serious attempts by scholars to provide an analytically rigorous definition of the term as both a policy and an ideology - and perhaps also as a discourse of governmentality in the Foucauldian sense (Larner, 2000) - it is still too frequently applied to any policy or practice that is deemed to be pro-market, such that even Adam Smith is sometimes associated with it. The boundaries between 'liberal' and 'neoliberal' are conveniently glossed over for the sake of polemic. There has also been little careful consideration given to the distinction between neoliberalism and neoconservatism. Both are identified with the New Right of the 1970s, although neither is synonymous with it. Habermas identifies a number of distinct and often contradictory ideologies that comprise the broader New Right movement which helped Reagan win the presidency in 1980, including the more traditional 'Catholic conservatives' and the populist 'Protestant fundamentalists' (Habermas, 
1989: 22). Of these disparate groups, of course, the neoliberals and the neoconservatives have been the most prominent and influential. Both, in fact, owe far more to classical liberalism than they do to classical conservatism, despite their association with conservative political parties, especially the Republican Party in the US. Neoliberalism can crudely be described as "liberalism without guarantees", while neoconservatism can be even more crudely described as "liberalism by any means necessary". Neoconservatism predates the New Right of the 1970s, emerging in the areas of cultural theory and social policy in the 1960s, its principal architects including a number of disgruntled liberals and radicals. The social policy of the neoconservatives has been built around the contradictions between democracy and liberty, most clearly articulated in the 'overload theory' of the state. According to this theory, presented in various ways by such commentators as Bell (1976) and Mead (1986), an excess of democracy results in a culture of excessive expectations of and demands upon the state which it is illequipped to satisfy, resulting in crisis. Such demands, articulated as rights, negate individual responsibility and reinforce a culture of dependency. Neoconservatives equate this excessive democracy with a kind of authoritarian populism that necessarily derives from mass culture, a position which distinguishes them from the new populists we shall discuss below.

The neoconservatives, then, ground their critique of state intervention largely in moral terms. They see themselves as champions of individual liberty as a classical liberal value in itself, with which comes personal responsibility. The neoliberals, by contrast, approach politics from the perspective of economic theory, and in doing so build upon, and contradict, the ideas of the classical and neoclassical liberals that preceded them. The classical liberals - Smith, Ricardo, Say and their ilk - postulated that an autonomous market, left to its own devices, with an emphasis on the promotion of enterprise, would result in equilibrium which would benefit all, just as Locke's political liberalism had defended the rolling back of state intervention on the grounds that human nature was essentially competitive but benign. The neoclassical liberals who succeeded them then inverted the relationship between supply and demand, suggesting that equilibrium is achievable if consumer demand is understood and matched, and duly initiated a bewildering trend across the social sciences to interpret all human action in terms of 'rational choice'. The neoliberals effectively abandon the promise of equilibrium and any pretence that the market is a tool for achieving 
social justice. It is not 'fair' in the sense that it is a universal social good. In this respect, they agree wholly with Marx - the marketplace is built on exploitation, some succeed precisely because others do not. Contra Marx they judge the market according to its own morality and not according to a wider social philosophy. Thus, the marketplace, and the system of exploitative social relations that underpins it, is fair so long as there is equal opportunity to succeed (or fail). This of course is the political philosophy that underpins Robert Nozick's (1974) theory of justice - equality of opportunity not outcome. But Nozick, like Hayek before him, is a libertarian and not a neoliberal theorist, economic freedom being in his philosophy only one manifestation of the wider concern with personal autonomy. The neoliberal extension of this idea, which foregrounds market freedom on purely economic grounds, is that equality of opportunity (and thus fairness) can be accommodated at a systemic level. The global capitalist system, the borderless world, assimilates everyone and everything and thus provides the conditions within which this equality of opportunity can, implicitly at least, be met, thus upholding the moral superiority of the market. In practice this justifies the supremacy of the most powerful economic actors such as the transnational corporations according to the kind of neo-Hobbesian, neo-Darwinian 'survival of the fittest' philosophy that neoliberalism infuses into liberalism.

Both the market fundamentalism of the neoliberals and the cultural fundamentalism of the neoconservatives necessarily demand an engagement with the globalizing processes, in stark contrast to the inward-facing protectionism of the 'realists' for whom the role of the state is principally to ensure the security of its citizens rather than engage unduly in international excursions and interventions. For both, the state, which should not intervene directly in the market, retains its political role as facilitator of the unregulated market - through management and planning, the implementation of privatization policies, and so on - and the defence of Western values respectively. The ideologues of neoliberalism have insisted that the global marketplace, without borders or tariffs, would ultimately bring a wealth of opportunities to nations and businesses so long as they are willing and able to be competitive (Bhagwati, 2004; Ohmae, 1990; Redwood, 1994), thus challenging development policies committed to state investment, economic regulation, protectionism and foreign aid (Bauer, 1981). The neoliberal insistence that countries in need of international financial support should as a condition of receiving this first abandon protectionist policies 
and open up their borders and their resources for foreign corporate investment and exploitation is probably the clearest illustration of the philosophy. If for the neoliberals the international arena is a realm of possibility and opportunity, for the neoconservatives it is a realm of conflict, and more pertinently, threat.

Drawing on Huntington's 'clash of civilizations' thesis, neoconservatives maintain that the growth and spread of rival value-systems represents a clear threat to the maintenance and supremacy of the Western value-system, and needs to be dealt with preferably through the use of soft power to impose Western values on other civilizations in the form of 'benevolent hegemony' (Kristol and Kagan, 1996), but by aggression if necessary. The important distinctions between the two in respect of foreign policy are neatly illustrated by a comparison between the 1991 Gulf War and the 2003 war against Iraq. The former was a neoliberal war, waged to protect the interests of capital following the Iraqi invasion of Kuwait. The latter was a neoconservative war designed to protect and promote a particularlydefined set of Western values, a 'way of life' (O'Byrne, 2003).

Though on close inspection ideologically distinct and at times contrary, neoliberalism and neoconservatism both emerged as significant political forces in the 1970s with the rise of the New Right in a number of Western countries. Subsequent political administrations in both the US and the UK have to a degree embraced a coalition of the two. Neoliberalism was at its most influential during the 1980s and 1990s, and was spearheaded by the premierships of Reagan, Bush Sr. and Clinton in the US, and Thatcher and (to a lesser extent) Major and Blair in the UK. It was superseded in the new century by the rival neoconservative tendency, for which Bush Jr. was the primary political figurehead, but which also appealed to the moralist in Blair during the later years of his term of office. The relative decline of neoliberalism as a political project during this time did not equate to its demise. Rather, many of the neoliberal policies promoted in the preceding decades had successfully cleared the way for transnational corporate interests to thrive independently of political action, allowing the Western state to embark on its 'cultural project' of neoconservatism. The crisis and demise of the neoliberal project came later, with the financial crisis of 2007-8, in which its limitations were unmasked, not only at the abstract level but in the everyday lives of many people around the globe, resulting in a public backlash against neoliberalism and in a political recognition that the unconstrained market might 
not bring about the equilibrium many thought it would (Gamble, 2009; O'Byrne and Hensby, 2011: 50-54).

The hegemony of the neoliberal-neoconservative social formation from the 1980s to the first decade of the new century was in all cases reliant upon its exploitation of the globalizing process. This process, however, takes many forms and it would be wrong to treat this project as synonymous with globalization per se ( $O^{\prime}$ Byrne and Hensby, 2011). Rather, it equates to what Sklair has called 'capitalist globalization' (Sklair, 2002), against which a counter-hegemonic alternative of 'socialist globalization' can be identified. I will return to this in the conclusion. If, for the sake of convenience, we follow the logic of treating the globalizing process as a complex network of various co-existent and sometimes contradictory conceptual and empirical forms (O'Byrne and Hensby, 2011), then the neoliberal globalist project is clearly one of liberalization, while the neoconservative globalist project is one of Americanization in response to balkanization. In contrast to both, the project of the new populism, which I turn to now, is one of deglobalization and renationalization, and thus sits outside, and stands in opposition to, the globalizing process in all its forms.

\section{The Political Ideology of the New Populism}

It was widely reported, as Trump was unexpectedly securing the Republican party nomination, that neither of the former presidents, George Bush or George W. Bush, would be endorsing his candidacy. The ideological pluralism of the Republican party being what it is, one could read this as an expression of the mutual dislike between the party's neoconservative and paleoconservative factions. But on a deeper level, it reflected a concern that the opinions and beliefs held by Trump and his supporters were alien to the party that, despite its position on the political Right, still saw the protection of fundamental values such as freedom and democracy as central to its identity. The Conservative Party in the UK had a slightly easier time formally distancing itself from the emergent populism promoted by the media-savvy Nigel Farage - at least he belonged to an altogether different party! A variation of it appears to have taken hold of the party under the post-Brexit May administration, centred largely around longstanding anti-cosmopolitan views in the party concerning both the European Union and, as we shall discuss below, the Human Rights Act. Yet it seems a little far-fetched to treat this administration as an equivalent manifestation of the new 
populism, not least because of its apparent lack of any coherent ideology whatsoever.

Trumpism, by contrast, does invoke clear comparisons with the more selfconsciously and ideologically populist parties in Europe. Across Europe, the partypolitical merry-go-round has seen both the emergence of new parties mobilized around Euroscepticism, anti-immigration and anti-Establishment populism, strategically located beyond the space occupied by the mainstream conservative parties, and the reinvention of older parties with roots in the more traditional Far Right and the overtly fascist movements of the early- to mid-twentieth century (Ignazzi, 2002). Superficially, and perhaps strategically, the former can be identified with a 'postmodern' or 'post-industrial' political shift and thus distinct from the latter. The 'new populism' is commonly attributed solely to these newer parties which occupy that particular political space to distinguish them from both the mainstream conservative parties to the left and the more overt racialist and nationalist ones to the right. In reality, if one interrogates the general direction taken by a number of these 'traditional' Far Right parties, the distinction is far from clear-cut. There has been a populist, Eurosceptic strand within these parties of the Far Right for considerably longer, often competing for power within the movement against the more orthodox fascist faction.

To demonstrate this, we can study the history of the Far Right in the United Kingdom. The first organized Far Right party of note, the openly pro-Nazi British Union of Fascists (later renamed the Union Movement) formed in 1932 by Oswald Mosley was something of an anomaly in that it saw itself as heavily pro-European, even advocating a single European state. Subsequent parties such as the National Front (formed in 1967 from an alliance of smaller parties) and the British National Party (which splintered from it in 1981) were considerably more 'orthodox' in their promotion of populist and arch-nationalist policies: anti-immigration, forced repatriation of non-white settlers and refugees, economic protectionism, prodeath penalty, and vehement opposition to what was then known as the Common Market.

Under the leadership of John Tyndall, the National Front firmly established itself as the fourth largest party in Britain during the 1970s, even if its relative success in increasing its percentage of the vote did not translate into parliamentary seats. Its leadership believed the party was in a good position to make a strong 
challenge at the 1979 UK general election, for which it stood a record number of candidates. This campaign turned into one of the most famous electoral disasters in party political history, but it was not the Left that saw off the fascist challenge. Rather, it was the Conservative Party's shift to the Right under the leadership of Margaret Thatcher which stole the proverbial rug from under its feet, paved the way for Tyndall's defeat as NF leader and departure from the party, and sent the Far Right into a state of chaotic disunity which lasted for a number of years.

Thatcher, of course, represented the New Right. Her policies revolved around a belief in possessive individualism and the restoration of individual responsibility, in privatization, economic deregulation, the dismantling of trade unions, and a general rolling-back of the state from the private affairs of citizens, accompanied by the stricter enforcement of law and order. Many of these policies were echoed by her American counterpart, Ronald Reagan. While the New Right was sufficiently broad to incorporate both neoliberals and - particularly in the US neoconservatives, it also successfully colonised the populist space on the political spectrum, thus clearly differentiating it from both traditional conservatism to the Left and the orthodox Far Right. With the populists of the Far Right now at home in the New Right, much to the chagrin of traditional conservatives, the Far Right as a movement was effectively split, with only the extremists, the neo-Nazis and white supremacists, still left on the margins.

The response from the increasingly disorganized Far Right, of which the National Front was still the major representative, was one of ideological in-fighting in the search for a new direction. Though the 'official' party position continued to be one of 'orthodox' national socialism, paramilitarism and white supremacism, two other factions quickly became influential: the populist 'Flag Group' which espoused Strasserite corporatism, and the 'Political Soldier' wing, the young radicals of the party who called for ethnic separatism rather than supremacism. Each claimed leadership (and in some cases legal ownership) of the 'official' party - the Strasserites renamed 'their' version of the party the National Democrats in an attempt to build a more popular appeal. Amidst this in-fighting, Tyndall's newly formed British National Party emerged as the largest party of the Far Right, although Tyndall himself was replaced as leader in 1999 by Nick Griffin, who had previously been a prominent figure in the separatist 'Political Soldier' wing of the NF. Under Griffin's leadership, the BNP solidified its ideological position as a 
populist party, ostensibly rejecting the racial supremacism of the past in favour of a cultural and ethnic nationalism, the protection of British interests and identity, and opposition to European Union membership became a significant articulation of this.

The appeal to cultural nationalism worked to an extent to increase the profile and the standing of the BNP during the new century, securing a reasonable share of the popular vote in major elections (relative to the number of constituencies contested) and picking up local government seats in its heartlands of east London and central Lancashire, plus parts of West Yorkshire and the West Midlands. Even so, it struggled to make any significant headway outside of these heartlands and its impact nationally remained marginal. Its decline corresponded, unsurprisingly, with the rise of the UK Independence Party (UKIP).

UKIP's origins did not, directly, lie in the complex shared history of the Far Right, but in the legacy of Thatcherism, into which much of the earlier populism had been absorbed in the 1970s and 1980s. The party had been founded in 1992 as the Anti-Federalist League by devout Thatcherite Alan Sked. In its formative years it was seen as a relatively obscure but widely organized single-issue party, always more likely to pick up protest votes at European elections, rather than one looking to solidify local support in particular heartlands, or contest at a national level. That it did this so successfully - in successive European elections during the new century it returned such a sizeable number of MEPs that one could no longer simply dismiss its achievements as protest votes - paved the way for its subsequent assault on the national stage. At the 2010 general election it contested 557 seats, winning none, but it gained two MPs by defection, both of whom were re-elected at by-elections. Local government successes followed in the next couple of years, including noticeably strong performances in former BNP heartlands. At the 2015 general election it contested 624 seats and although it won only one of them (ex-Tory defector Douglas Carswell in Clacton) it was, in terms of its percentage of the public vote, clearly the third largest party in the country.

The relative success of UKIP during this period clearly reflected the general appeal of its populist position in a way parties such as the BNP were unable to achieve, due in no small part to their more overt association with the 'old' Far Right. The party successfully sold itself as a peculiar blend of libertarianism, neoliberalism 
and political realism, very much the heir to the Thatcherite New Right, and capturing the essence of what had appealed to the populists of the Far Right in the first place. However, if its 'core' policy demand was always withdrawal from the European Union (and it played a reasonably important part in securing the 'Brexit' vote in 2016), its rhetoric gradually shifted towards the issue of immigration.

The distinction between populist parties with roots in the old Far Right and those which emerged as part of the 'post-industrial' politics might be applicable in the UK, as a means of distinguishing the BNP from UKIP, but it is perhaps less clear elsewhere. Both the Freedom Party in Austria and the National Front in France have sought to move beyond early associations with the older movement. The former began life as a neo-Nazi party in 1955 but underwent an ideological shift in the 1980s to embrace populist and libertarian beliefs. The latter was formed in 1972 out of an alliance of various Right and Far Right parties. Led for many years by Jean-Marie Le Pen, it began its shift to populism in the 1990s, and in 2002 its leader saw off the challenge of the socialist candidate Lionel Jospin for the right to contest the final round of the presidential election against the conservative favourite Jacques Chirac. Though the result was a resounding victory for the establishment, it nonetheless marked a significant shift in the National Front's status in French politics. The party's populist shift continued following the election of Marine Le Pen as leader in 2011 (her father and predecessor was expelled from the party for making neo-Nazi comments), and saw it win $25 \%$ of the vote in the 2014 European elections and once again finish second in the 2017 presidential election, this time with nearly $34 \%$ of the vote. In Germany, the Alternative for Germany party, which won $12.6 \%$ of the vote and 94 seats in the 2017 federal elections, seems to have shifted in the opposite direction, having begun life as a relatively moderate neoliberal party before embracing a more nationalistic rhetoric.

Many of the new populist parties across Europe are united within either the European Alliance for Freedom or the generally less 'moderate' Movement for a Europe of Nations and Freedoms, and keen to distinguish themselves from such groupings as the Alliance of European National Movements which are more closely associated with the traditional Far Right. It continues to be a core priority of the populist movement that it is identified as something 'new' - an image that 
is probably easier for such parties as UKIP and AfD to present than for those which have sought to shift 'inwards' from the Right. Nonetheless, whichever direction such parties have taken, they have to an extent met in a space on the political spectrum intended to distinguish them from both the old Far Right and the neoliberal New Right, but more explicitly from the latter. As part of its populist shift, for example, the National Front in France adopted a protectionist economic policy as a conscious articulation of its anti-globalist sentiment. Quasisocialist economic policies such as welfare provision and minimal nationalization of core services are evidence of a party's shift from neoliberalism to populism. In the UK, public support for the National Health Service is such that no truly populist party can successfully advocate its full privatization. When populist protectionism extends into the field of international relations, it takes the form of ardent non-interventionism. Populist parties thus opposed the neoconservative military interventions in the Middle East, and some have come out as outright critics of what they perceive to be an imperialistic project. The alleged friendship between Jean-Marie Le Pen and Saddam Hussein brings to mind the aforementioned shift in the National Front in Britain in the 1980s from supremacism to separatism. The new populist racism is grounded in ethnic nationalism and embedded in an anti-immigration discourse rather than in the racialism of its predecessor, but it remains an articulation of the same underlying world-view.

In short, just as neoliberalism and neoconservatism represent distinct articulations of the New Right, orthodox fascism and contemporary populism relate to one another as rival articulations of the Far Right. The table below summarises their respective positions:

\begin{tabular}{|l|l|l|}
\hline $\begin{array}{l}\text { The New } \\
\text { Right }\end{array}$ & Neoliberalism & $\begin{array}{l}\text { Globalist project centred on market } \\
\text { fundamentalism, the liberalization of } \\
\text { borders and the unregulated free market; } \\
\text { Libertarian polity }\end{array}$ \\
\cline { 2 - 3 } & Neoconservatism & $\begin{array}{l}\text { Globalist project centred on protection and } \\
\text { promotion of Western cultural values; } \\
\text { Authoritarian polity }\end{array}$ \\
\hline
\end{tabular}




\begin{tabular}{|l|l|l|}
\hline The Far Right & Populism & $\begin{array}{l}\text { Nationalist project centred on opposition to } \\
\text { immigration on cultural and separatist } \\
\text { grounds; Protectionist economic policy } \\
\text { allied to support for business and } \\
\text { enterprise; Libertarian polity }\end{array}$ \\
\cline { 2 - 3 } & Fascism & $\begin{array}{l}\text { Nationalist project centred on racialism and } \\
\text { supremacism; Protectionist economic policy } \\
\text { allied to statist project; Authoritarian polity }\end{array}$ \\
\hline
\end{tabular}

So much for the Europeans: where does Trump, or more specifically, 'Trumpism' (if there is such a thing), fit into this? The relationship between Trump's populist appeal, the European populists, and the older fascist movements has been the topic of considerable debate (see, for example, Bessner and Sparke, 2017; Fraser, 2016; Giroux, 2018; Judis, 2016; Mudde, 2015). Writing for the Washington Post, Cas Mudde has highlighted clear differences between the policies and character of Trump himself and those of his European populist contemporaries, while acknowledging that there are similarities between their groups of supporters (Mudde, 2015). In Mudde's words, Trump is not a populist so much as an "antiestablishment elitist." The key distinction appears to be that Trumpism is in the tradition of paleoconservatism rather than Far Right nationalism and fascism. Mudde considers Trump's views on immigration, for example, more nuanced than those of the European populist Right, and falling short of condemning multiculturalism per se. Of course, it would be extremely difficult for any serious politician in the United States to present the kind of essentialist nativism advocated by some more extreme voices on the European Far Right, given the significant and deeply internalized role immigration has played in US history. Another significant factor that distinguishes the American from the European context is the party-political system. Although European centre-right conservative parties tend to be less ideologically singular that most others on the political spectrum, this is nowhere near to the extent of the United States Republican Party, an extremely broad coalition of social conservatives, paleoconservatives, neoconservatives, neoliberals, libertarians, Christian democrats and Christian fundamentalists most of whom would, in the European context, have formed separate and competing parties. Identifying Trump with the paleoconservative tendency within the party of course makes perfect sense in a superficial way- 
many of his policies appeal more to that faction than to any of the others, but it is stretching credulity to treat him as an outright successor to Pat Buchanan, never mind as an inheritor of the legacy of Edmund Burke.

Such reasons might very well make Trumpism a peculiarly American variant of right-wing populism, and it seems reasonable to locate it in part, as Judis (2016) does, within a long-standing American tradition, but it is disingenuous to fully disassociate it from the broader movement. If anything, the apparent reluctance of Trump himself to commit to a position on certain key policy areas singles him out as the populist par excellence. Contrary to the traditional Far Right, which has always been heavily immersed in its defining ideology, populism celebrates pragmatism and 'common sense' over ideology and intellectualism. This is its appeal - do what needs to be done, rather than what the 'rules' tell you to do. For European populists such as Farage, the enemy of common sense is bureaucracy - especially the bureaucracy of the European Union and other such international institutions. Trump's anti-establishment agenda appeals to precisely the same tendency which, whether in Europe or America, quickly becomes its own rationale. This rampant pragmatism, with its appeal to common sense rather than intellectualism, justifies itself in opposition to a set of concepts, not only 'bureaucracy' but, 'political correctness', 'multiculturalism' and 'human rights', without any respect for what those terms might actually mean. Logic gives way to recursion.

To refer to Trumpism as a manifestation of this broader populism and, by extension, of fascism, might seem extreme, and Bessner and Sparke (2017) are right to advise caution when making such parallels, but it is appropriate. That it is located within the democratic process is not sufficient grounds to differentiate the Trumpist agenda from fascism, as Judis (2016) suggests, precisely because the process ceases to be democratic when it is dictated by recursion. As a form of political rhetoric, recursion is the negation of ideology, logic and justice.

Everything is right because we are told it is right, and to suggest otherwise is to stand as an enemy of common sense and in the way of 'getting the job done'. Hansen's phrase "a quiet kind of fascism" comes to mind here. Across Europe in the mid-20 ${ }^{\text {th }}$ century fascism was announced and celebrated with full pomp and circumstance. Its current manifestation, including its encroachment into the spheres of everyday life, is far less conspicuous. Fascism begins, one might say, 
when those rules of logic and reason from which accountability is derived are discarded. It happens in the workplace and is a distinctive characteristic of managerialism, an ever-present feature of late capitalism. Ironically, it is nurtured in the same technical-rational processes that result in the very bureaucracies the populists claim to rail against. In 2011, Robinson and Barrera identified the primary features of fascism in the new century, and warned of its impending arrival in the mainstream of American politics. At the time, they conceded that it lacked a 'charismatic leader'. That is clearly no longer the case.

\section{The War on Human Rights}

A clear manifestation of the new populist tendency, which I have suggested is a contemporary manifestation of fascism, is its outright rejection of the culture of human rights. In a purely logical sense, it seems entirely absurd for any reasonably intelligent human to be 'against' human rights: why would one willingly surrender to slavery and servitude? However, politics is not grounded in linguistics or logic. The populist attack on 'human rights' is a language game of sorts: one is not supposed to treat 'human rights' logically or literally, but to view it as a signifier for a broader culture of inclusion that puts 'the Other' on a par with everyone else. The attack on human rights is a denial of 'the Other's rights', not 'yours'. The 'Other', in this sense, is whichever marginalised figure can be suitably demonized to mobilize populist support: the foreigner, the refugee; the black in an audience of whites; the Muslim in a Western country; the person of non-heterosexual orientation; the prisoner, and so on. The on-going debate around gay marriage in many parts of the world is a case in point, framed as it within the context of access to a 'club' which exercises a particular form of distinction. The populist argument does not say, "we don't like gay people". Rather, it says, "gay couples can be together, but they can't marry, because marriage is a club only 'we' belong to". The language thus shifts from supremacism to separatism, but social exclusion and the associated power dynamic are satisfactorily maintained nonetheless.

The rhetorical shift from supremacism to separatism which characterises the restructuring of the Far Right from fascism to populism is a response to the globalizing processes of the late twentieth century. The cosmopolitan culture of human rights, the inclusion of the 'Other', carefully manipulated, becomes an easy target. The populist politician can condemn the negation of human rights 
abroad while actively participating in their negation at home, because 'our' club is different to 'their' club. The populist war on human rights is a war not against the protection of those rights 'we' enjoy, but against a culture that dares to suggest others might also be allowed the same privileges. In the UK, this has become closely entwined with debates over national sovereignty. When rights are determined by Others, it stands to reason those Others, who do not belong to our 'club', will view them differently. Plans to scrap the Human Rights Act and replace it with some kind of 'British bill of rights' is a case in point (O'Byrne, 2016: 2). The proposed change will not impact in any obvious way on 'our' rights - 'we' will still enjoy the same freedoms from slavery and servitude, the same opportunities to participate in the political process, the same legal protections, and so on. The actual difference may not be obvious, but it is profound. In so far as the Human Rights Act effectively embeds the European Convention on Human Rights into UK law, and the European Convention is part of the international human rights system that defines rights as universal and inalienable properties of all people, and not just the citizens of that particular country, it poses a challenge to the exclusivity of 'our club'. A British bill of rights, by contrast, would enable the authorities to confer those exact same rights upon those who are members of the 'club', but they would no longer be universal, because non-members would not automatically be entitled to them, and they would no longer be inalienable, because their conferment would be within the power of those authorities (O'Byrne, 2016: 24, 126). Thus, the populist attack on human rights, articulated as it is in the UK as an attack on the overly bureaucratic European is an obvious case of social closure, or distinction.

It is reasonable at this stage to wonder how, if at all, different this is from the treatment of human rights within the neoliberal and neoconservative paradigms. From a Left, or even a liberal perspective, both can be accused of riding roughshod over the culture of human rights. The market fundamentalism of the neoliberals, after all, cares little for the protection of rights, and in some cases, such as the protection of the rights of workers, stands in opposition to it. Similarly, a neoconservative such as George W. Bush cannot have been overly plagued by human rights concerns when signing so many death warrants in Texas. There is of course truth in this. But the neoliberal market fundamentalist has no interest in actively opposing the international human rights system. Indeed, she or he is in no small part empowered by it. The market thrives on the very 
freedoms that the human rights regime entails. Fraser (2016) has referred to the apparent alliance of neoliberal economics and liberal social policy as 'progressive neoliberalism', and associates it largely with the Democratic party (not only the Clintons but also Obama) in the US, and, we might add, Cameron's Conservative party in the UK (recognising the former PM's advocacy of gay marriage, for example). In this sense, then, 'liberalization' carries a dual meaning. Exclusionary or discriminatory political practices make bad business sense. There is some irony in the fact that, with his background in transnational business, President Trump is a beneficiary of this.

The populist war on human rights is also markedly distinct from its neoconservative predecessor. The neoconservative engagement with - which some might reasonably also call a war on - human rights, marshalled by the likes of George W. Bush and Tony Blair and given credibility by liberal academic apologists such as Richard Rorty and Michael Ignatieff, was fought in the name of human rights, and reached its peak in the US-led invasions of Afghanistan and Iraq. To return to an earlier example, the 2003 Iraq war was driven by the strategic importance of protecting the so-called Western way of life, making the protection of capitalist interests (which are crucial to that value-system) a happy by-product. This inverted the rationale for the 1991 Gulf War, a neoliberal war fought to protect the interests of capital, in which human rights concerns were decidedly secondary (O'Byrne, 2003). The neoconservative manifesto is thus defined by a passionate commitment to the values of Western liberal individualism and the willingness to promote these values through military as well as political, economic or cultural means - a so-called 'muscular liberalism'. It is therefore a war within human rights, in which the ideological battleground is the discourse of rights itself, which is every bit as crucial in the eyes of the combatants as the physical battlegrounds of the Middle East.

If the neoconservatives would seek to colonise the discourse of rights by making it synonymous with Western values, and the neoliberals would keep it at arm's length while quietly thriving on the culture of freedom it promotes, the populists would reject it outright. This is evident in the policies of the Trump administration in the US and, less ideologically, in the more populist wing of the British Conservatives, as much as it is in the more overt anti-human rights rhetoric of the Far Right and UKIP. For them, contra the neoliberals and the neoconservatives, 
the culture of human rights represents a direct threat. Theirs is a war against human rights - not against rights per se, as we can see with the debate on human rights legislation in the UK, but against human rights - which places them squarely in the same camp as the fascists they have strategically sought to differentiate themselves from.

\section{What Is to Be Done?}

The new populism of the Right, whether in Europe or in Trump's America, is most appropriately seen as a reconstructed manifestation of fascism within the context of the globalizing process. There is, of course, debate on the exact nature of the relationship between this new populism and the neoliberal project. Some concede that this populism is best described not as fascism outright but as a blend of fascism and neoliberalism (Bessner \& Sparke, 2017). Others see it as a rejection of 'progressive neoliberalism' rather than neoliberalism per se (Fraser, 2016). Still others suggest that it is a backlash against the perceived effects of the global economy, which becomes a scapegoat, detracting attention from the inherent failings of the system itself (Rodrik, 2017). It is certainly the case that the populists, as inheritors of the fascist legacy, are quick to exploit popular anxieties about the global economy to incite hatred of the Other and not quite so quick to invite criticism of the capitalist class.

Such strategic scapegoating of capitalist globalization for the purpose of inciting racism and xenophobia notwithstanding, it is clear that the defining characteristic of the new populism is a rejection of the globalizing process in all its forms, and thus of the structural conditions which made neoliberalism and neoconservatism possible in the first place. It is a rejection of liberalization which neoliberals once championed as heralding the 'end of the nation-state'. It is a rejection of transnationalization, whether in reference to the influence of transnational institutions, laws, corporations or classes. It is a rejection of creolization (and to an extent McDonaldization) in the name of cultural and ethnic separatism and local difference. It is, if not an outright rejection of balkanization as a conceptual framework, an unequivocal rejection of the neoconservative rallying cry for an imperialist moral crusade, akin to Americanization. It rejects globalization (used here as a process driven by an identification and engagement with the world as one place) for being too abstract. It rejects polarization on the grounds that, quite 
simply, the social and economic well-being of the Global South is "not our problem".

In order to best counter the rise of this new populism, its opponents need to better recognise the situation for what it is. Large sections of the political Left, for a start, need to start rethinking their priorities. In the UK, the Left's response to Brexit has been somewhat disingenuous. In particular, the arguments in favour of withdrawal from the European Union put forward by prominent voices in the socialist movement - that the European Union is merely a puppet of global capitalism, designed to benefit corporations and governments rather than citizens - come across as if from a different time. While there may be truth in the argument, it might just as easily be made of the United Nations, the associated organs of which have for some time been the drivers of economic globalization. Are we then to campaign for withdrawal from the UN? The socialist movement is caught in an ideological dilemma, and seems willing to forget its commitment to internationalism in its desire to break free. In a contest of undesirable alternatives, an economic and political protectionism driven primarily by nationalistic, neo-fascist sentiment is surely not a preferred option to continued participation in a hugely flawed international system.

This seems particularly pertinent when one reconsiders Leslie Sklair's (2002) pioneering theorization of the dialectics of globalization. The fundamental point of Sklair's argument is that capitalist globalization - the project of neoliberals and neoconservatives alike- is sustained as a hegemony by the ideology of consumerism, and can be countered by an alternative project of socialist globalization that is sustained by an ideology of human rights. In effect, Sklair recognizes that global capitalism demands, in response, global socialism. If the neoliberal-neoconservative project has been eroded and replaced by a new populism which is self-consciously a rejection of the globalizing process, then must it follow that its counter-hegemonic negation is a left-wing nationalism? Though there is undeniably a strong anti-globalist sentiment on the margins of the political Left, the actual and more meaningful shift towards a left-leaning populism in direct contrast to that on the political Right might help us understand the relative popularity of Sanders in the US and Jeremy Corbyn in the UK. In terms of countering the new populism of the Right, the political necessity of this is 
undeniable. Whether it provides us with a clear ideological direction for the Left in the longer term, though, is debatable.

The socialist and social democratic Left is unlikely to endorse, in response to the populist anti-globalism of the Right, an ultra-globalism of the kind that has driven some to call for world government as the only antidote to nationalist parochialism. However, to abandon entirely a commitment to cosmopolitanism is surely to venture into a political and ethical cul-de-sac. Concerns about the organization of transnational institutions and laws need not be synonymous with a rejection of transnational values. Hannah Arendt's concerns over the impotency of human rights agreements to deal with the plight of refugees following the Second World War did not amount to a critique of the values underpinning them. Sklair's belief that the concept of human rights belongs in the ideological armoury of the Left still holds true: a modern manifesto of the Left can and should be a manifesto that is driven by the values of human rights in totality-economic, social, cultural, civil, political and environmental - to stand in opposition not only to the selective picking-apart of the rights discourse by the neoconservatives and neoliberals, but to their fundamental negation by the populists.

\section{Bibliography}

Bauer, P. (1981) Equality, the Third World, and Economic Delusion Cambridge, Mass: Harvard University Press

Bell, D. (1976) The Cultural Contradictions of Capitalism New York: Basic Books Bessner, D. and Sparke, M. (2017) 'Nazism, Neoliberalism, and the Trumpist Challenge to Democracy' Environment and Planning A: Economy and Space 49, 6, 1214-1223

Bhagwati, J. (2004) In Defense of Globalization Oxford: Oxford University Press Fraser, N. (2016) 'Progressive Neoliberalism versus Reactionary Populism: A Choice that Feminists Should Refuse' Nordic Journal of Feminist and Gender Research 24, 4, 281-284

Gamble, A. (2009) The Spectre at the Feast: Capitalist Crisis and the Politics of Recession Basingstoke: Palgrave Macmillan 
Giroux, H. (2018) The Public in Peril: Trump and the Menace of American Authoritarianism New York: Routledge Habermas, J. (1989) The New Conservatism Cambridge: Polity Press Hansen, S. (2017) Notes on a Foreign Country: An American Abroad in a PostAmerican World New York: Farrar, Straus \& Giroux

Huntington, S. (1996) The Clash of Civilizations and the Remaking of World Order New York: Simon \& Schuster

Ignazi, P. (2002) 'The Extreme Right: Defining the Object and Assessing the Causes'. In Schain, M., Zolberg, A. R. and Hossay, P. (eds) Shadows over Europe: The Development and Impact of the Extreme Right in Western Europe New York: Palgrave

Judis, J. (2016) The Populist Explosion: How the Great Recession Transformed American and European Politics New York: Columbia Global Reports

Kristol, W. and Kagan, R. (1996) 'Toward a Neo-Reaganite Foreign Policy' Foreign Affairs July / August

Larner, W. (2000) 'Neo-liberalism: Policy, Ideology, Governmentality' Studies in Political Economy 63, 5-25

Mead, L. (1986) Beyond Entitlement New York: Free Press

Mudde, C. (2015) 'The Trump Phenomenon and the European Populist Radical Right' The Washington Post https://www.washingtonpost.com/news/monkeycage/wp/2015/08/26/the-trump-phenomenon-and-the-european-populistradical-right/?utm_term=.d6080f829358

Nozick, R. (1974) Anarchy, State and Utopia Oxford: Basil Blackwell

O'Byrne, D. J. (2003) 'The Discourse of Human Rights and the Neo-Conservative Discourse of War' Mediactive 3, 13-22

O’Byrne, D. J. (2016) Human Rights in a Globalizing World London: Palgrave O'Byrne, D. J. and Hensby, A. (2011) Theorizing Global Studies Basingstoke: Palgrave 
Ohmae, K. (1990) The Borderless World: Power and Strategy in the Interlinked Economy New York: Free Press

Redwood, J. (1994) The Global Marketplace London: HarperCollins

Robinson, W. and Barrera, M. (2011) 'Global Capitalism and Twenty-First Century Fascism: A US Case Study' Race \& Class 53, 3, 4-29

Rodrik, D. (2017) 'Populism and the Economics of Globalization' CEPR Discussion Paper No. 12119

Sklair, L. (2002) Globalization: Capitalism and Its Alternatives Oxford: Oxford University Press

Note

This paper is written for submission to a scholarly journal and should not be cited without the express permission of the author. 